Peter West

Trinity College, Dublin, Ireland

ORCID: 0000-0003-3862-142X

e-mail: westp@tcd.ie

\title{
Berkeley on the Relation Between Abstract Ideas and Language in Alciphron VII
}

DOI: http://dx.doi.org/10.12775/RF.2018.036

\section{Introduction}

The role that Berkeley's anti-abstractionism - his commitment to the existence of only particular ideas and his rejection of the existence of abstract ideas - plays beyond the Introduction to the Principles of Human Knowledge is still contested by commentators. There are clear signs elsewhere in the body of the text, and in other texts, that Berkeley sees abstractionism as prevalent amongst his opponents, 'materialists' (see PHK §§ 4-5; DHP 177, 192-193, 222). ${ }^{1}$ For that reason, commentators like Margaret Atherton and Martha Brandt Bolton have argued that Berkeley's anti-abstractionism is in fact a premise in his overall argument for immaterialism. ${ }^{2}$ Conversely, Samuel Rickless and Jonathan Bennett have argued that anti-abstractionism does not serve as a premise in Berkeley's reasoning towards immaterialism. ${ }^{3}$ While Berkeley never gives an

1 For a critical discussion of Berkeley's treatment of abstract ideas beyond the Principles Introduction see Bennett 1971, 42-46.

2 According to these commentators, accepting the non-existence of abstract ideas is essential for arguing for the non-existence of matter. See Atherton (1986); Bolton (1987). See also Laurent Jaffro 2013, 134.

3 Rickless argues that anti-abstractionism simply plays a helpful role in making materialism seem implausible or inconsistent with common sense. Bennett denies 
explicit indication of the role that anti-abstractionism plays in his arguments against materialism, he does explicitly tie his aims in the Introduction to the nature and use of language. In what constitutes the only explicit 'signpost' about the role of the Introduction, Berkeley writes:

In order to prepare the reader for the easier conceiving of what follows, it is proper to premise somewhat, by way of introduction, concerning the nature and abuse of language. (PI § 6)

Yet, despite what this signpost suggests, Berkeley spends most of the Introduction developing his case against the existence of abstract ideas, making only a few remarks on the significance of that argument to our use of language. Kenneth Pearce has emphasised these aspects of the Introduction and endeavoured to show that Berkeley's arguments here and throughout the Principles are more closely related to language than commentary tends to acknowledge. ${ }^{4}$ Beyond that, however, little has been done to examine the relationship between anti-abstractionism and Berkeley's philosophy of language beyond the Principles Introduction. My aim in this paper will be to do just that; by focusing on Berkeley's treatment of abstract ideas in dialogue seven of Alciphron: or, the Minute Philosopher. ${ }^{5}$

In Alciphron, Berkeley presents an "apology for the Christian religion, against those who are called free-thinkers" [AMP, frontmatter]. Over the course of seven dialogues, two figures, Euphranor and Crito, defend the utility, plausibility, and truth of both natural religion and Christianity against the free-thinkers Alciphron and Lysicles. In dialogue seven, the focus is on the meaningfulness and significance of religious language and whether certain words that are central to Christian scripture can truly be said to be meaningful. The discussion largely focuses on whether the term 'Grace', which Alciphron identifies as the most widely discussed term in Christian discourse (AMP 7.4), is meaningful. Alciphron argues that 'Grace' cannot be a meaningful term, because the necessary and sufficient condition for being a meaningful term is that it suggests an idea in the mind (AMP 7.2). Alciphron argues 'Grace' is but an "empty name" (AMP 7.4). Euphranor, in response, argues that Alciphron's criterion for meaningfulness, if it were accepted, would have repercussions that go well beyond religious discourse. In fact, he maintains, if Alciphron were

that there is any relation between anti-abstractionism and immaterialism. See Bennett 1971, 43; Rickless 2014.

4 Pearce 2017a, 13.

5 I thus reject what David Berman calls the "generally accepted view... that [Alciphron] has little significant connection" with Berkeley's early philosophy. See 1993 (7). 
right then we would have to totally re-assess our understanding of what kinds of discourse are and are not significant.

This dialogue is, as Pearce puts it, "Berkeley's most detailed and systematic treatment of the philosophy of language". ${ }^{6}$ If Berkeley has anything significant to say about the relationship between abstract ideas and language, then this is where we ought to expect him to say it. In what follows, I will argue that Berkeley's treatment of abstraction and the possibility of abstract ideas in this dialogue is revealing. I will argue Berkeley's failure to present the antagonist of the piece, the titular Alciphron, as a Lockean abstractionist is significant. The reason for this, I will argue, is that Berkeley sees abstract ideas as explanatory posits which thinkers are only willing to commit themselves to once they have accepted the Lockean theory of meaning. Explanatory posits are the kinds of things of which it can be said ' $x$ must exist in order to explain phenomena $y$ '; they are inferred and not observed. As a result, as he puts it in the Principles Introduction,

he that knows names do not always stand for ideas, will spare himself the labour of looking for ideas, where there are none to be had. (PI § 24, my emphasis)

Berkeley believes were it not for the widespread acceptance of the Lockean theory of meaning, there would not be a widespread belief in the existence of abstract ideas. ${ }^{7}$ The correlation between the two, he argues, is not a coincidence. I argue that this view is consistent with Berkeley's treatment of abstract ideas in the Introduction to the Principles.

The structure of my argument is as follows. Firstly, I outline the 'suggestive' theory of meaning Alciphron puts forward in dialogue seven and explain why it renders the term 'Grace' meaningless. I then outline Euphranor's reply, which is where Berkeley develops an alternative theory of meaning in language. Secondly, I examine Berkeley's treatment of abstract ideas in this dialogue with a particular emphasis on how the figure of Alciphron is presented differently in earlier and later editions of the text. In the third section, I develop the claim that, for Berkeley, abstract ideas are explanatory posits. Finally, I conclude that, for Berkeley, anti-abstractionism is not a premise in his argument for an alternative theory of meaning but is rather an outcome of that theory. One of the broader implications of this reading, I suggest, is that it emphasises the

6 Pearce 2017a, 54. See also Berman 1993, 6.

7 For the purposes of this paper, I will refer to the view that Berkeley rejects in AMP 7 as a 'Lockean' theory of meaning. However, as Pearce has shown, this view was accepted by many other thinkers in the seventeenth century, justifying Berkeley's claim that is a 'received opinion' (PI § 19). See Pearce (2017a), ch.1. The 'suggestive' theory, in what follows, specifically refers to Alciphron's presentation of that theory. 
empirical nature of Berkeley's approach to knowledge and the key role of observation and experience in his theory of ideas.

\section{Empty Names}

\subsection{The 'Suggestive' Theory}

At the beginning of dialogue seven, Alciphron suspects that much of Christian teaching goes unexamined and that members of the church pay a mere "blind reverence" to scripture. As he puts it, "the shallow mind of the vulgar, as it dwells only on the outward surface of things and considers them in gross, may easily be imposed upon". Alciphron argues that in any area of discourse we ought to avoid affirming, denying, reasoning about, or believing in, "empty notions, or to speak more properly, mere forms of speech, which mean nothing and are of no use to mankind" (AMP 7.1). ${ }^{8}$ We ought to scrutinise the terms we use in order to make sure that they are meaningful.

In order to examine the language we use and determine whether it is meaningful, Alciphron claims that "we have nothing to do but lay aside the words, and consider the ideas suggested by them." (AMP 7.2) If it turns out that a word fails to suggest an idea then that word is meaningless and "the speaker utters nonsense" and may as well be making a mere sound (like an animal). ${ }^{9}$ Alciphron's 'suggestive' theory of meaning is best characterised by his claim that: "Words are signs: they do or should stand for ideas, which so far as they suggest are significant [my emphasis]". When people fail to scrutinise the words they use - and consequently the meaningfulness of the discourse they engage in - they are liable to end up in a position where "their minds are rather stored with names than ideas, the husk of science than the thing" (AMP 7.2).

Alciphron's view is that religion, and in particular the teachings of the Christian church, is guilty of having focused more on the 'husk' of its science than 'the thing'. As he puts it, Christianity is guilty of having "raise[d] a dust and dispute[d] about tenets purely verbal" (AMP 7.3). Alciphron develops his argument by focusing on the term 'Grace', which is so fundamental to Christian discourse, he argues, that the legitimacy of faith in the Christian religion stands or falls with the meaningfulness of it. Alciphron proceeds to argue that the term is meaningless because

8 There is a parity, he claims, between the rules of reasoning in religion and in any other 'science' (AMP 7.3).

9 Similarly, Locke compares those who use words before or without learning what ideas they stand for to parrots. See EHU 3.2.7. 
whenever I laid aside the word Grace, and looked into my mind, [I have always found] a perfect vacuity or privation of all ideas. And, as I am apt to think men's minds and faculties are made much alike, I suspect that other men, if they examined what they call Grace with the same exactness and indifference, would agree with me that there was nothing in it but an empty name. (AMP 7.4)

Despite its constant and familiar use in Christian discourse, Alciphron argues, 'Grace' is an empty name: a term failing to suggest an idea in the mind of speaker or hearer. ${ }^{10}$ As a consequence, it turns out that Christian discourse is all 'husk' and no 'thing'. In other words, disputation concerning Christian doctrine and scripture is of little importance because its terminology fails to provide the mind with objects to think and reason about.

Alciphron's 'suggestive' theory is a version of the Lockean theory of meaning (and in what follows I use the terms interchangeably) $\cdot{ }^{11}$ In book three of the Essay, Locke explains that words are "signs of internal conceptions" and that they

stand as marks for the ideas within [one's] own mind, whereby they might be made known to others, and the thoughts of men's minds be conveyed from one to another. (EHU 3.2.1)

Alciphron's approach is consistent with this view; in both cases, the role of words is to signify ideas in the mind. Alciphron also shares Locke's account of what makes for a meaningless term. Unless there is a "constant connection between the sound and the idea; and a designation, that one stand for the other" Locke explains, that sound, or word, is nothing more than "insignificant noise" (EHU 3.2.7). If a word, upon scrutinization, turns out not to signify an idea, then that word remains an "empty sound". (EHU 3.10.2)

Locke himself, however, never explicitly uses this theory of meaning to undermine the significance of Christian doctrines. ${ }^{12}$ In that regard, Alciphron's argument is much closer to one developed by Toland in his Christianity Not Mysterious. Toland has two motives; firstly, to show that reason and Christian scripture are neither inconsistent nor incompatible,

10 By 'empty name' Alciphron simply means a word that fails to signify an idea (and is therefore meaningless). This is to be distinguished from contemporary uses of 'empty name' where it means a word that fails to refer but is nonetheless meaningful (e.g. 'Pegasus').

11 For a discussion of potential inconsistencies between Locke and Alciphron, see Ott 2003, 118-124.

12 There are certainly signs that Locke was concerned (like Alciphron) about doctrinal terms going unexamined (see EHU 3.10.2, 4.18.3). But Locke's point is hardly the same as Alciphron's polemic against the plausibility of faith in Christian religion. 
and secondly, to show that (since a mystery, by definition, is contrary to or above reason) there are no mysteries in Christian scripture..$^{13}$ As he puts it in the Preface; "I hope to make it appear, that the Use of Reason is not so dangerous in Religion as it is commonly represented" (CNM, Preface 6). What Toland objects to is those who defend the importance of Christian mysteries; those who would have it that Christian teachings remain mysterious and obscure. As he puts it, "the true Religion must necessarily be reasonable and intelligent" (CNM, Preface 12) ${ }^{14}$ Toland's understanding of what indicates a notion is contrary to reason is its being "repugnant to clear and distinct Ideas" (CNM 2.1). In relation to Christian doctrine, this entails that "if any Doctrine... be contrary to Reason, we have no manner of Idea of it". ${ }^{15}$ If a doctrine is reasonable, Toland maintains, then we can conceive of ideas corresponding with it.

On Toland's view, if it is insisted that notions like grace are mysterious, and thus contrary to reason, then terminology pertaining to them is meaningless. So we must identify the ideas annexed to the terms we use. However, neither Locke nor Toland goes so far as to make the argument that Alciphron puts forward in dialogue seven. ${ }^{16}$ Neither thinker explicitly argues that Christian terminology is meaningless. What is at the core of all these views, though, is the assumption that words ought always to correspond with ideas. It is this claim that Berkeley seeks to challenge in dialogue seven. I outline that response in what follows.

\subsection{Are Empty Names Meaningless?}

The first thing to note about Euphranor's response to Alciphron is that he does not try to contest that 'Grace' fails to stand for an idea. This is immediately indicative of Berkeley's approach to the relation between words and ideas. It quickly becomes clear this is because Euphranor does not accept the starting point of his opponent's argument: the claim that meaningful words must always suggest ideas. ${ }^{17}$

Since words, it is agreed, are signs, Euphranor's first move is to emphasise that signs are not always used in the way that Alciphron describes. For example, he considers how 'counters' (like poker chips) are used around a card-table. He points out that they "are used, not for their own sake, but only as signs substi-

13 See CNM, frontmatter; Pearce 2017b (474).

14 See also CNM, Preface 10.

15 See also CNM 2.4.

16 On the extent to which Alciphron reflects Toland's views see Berman 1993 $(10,12)$; Pearce 2017a (56).

17 Consider again Berkeley's claim in PI that "he that knows names do not always stand for ideas, will spare himself the labour of looking for ideas, where there are none to be had" (PI § 24). 
tuted for money, as words are for ideas" (AMP 7.5, my emphasis). Counters are substituted in for the sum of money they signify; likewise, words are substituted for the ideas they suggest. Euphranor emphasises that for the counters to serve their purpose (as signs) it is not necessary every time they are used "to frame an idea of the distinct sum or value that each represents". So long as the game continues, we attend to the counters as opposed to the sums of money themselves (for example, I judge whether I am doing well based on the size of my pile of counters). Euphranor's first point, then, is that once signs are substituted for whatever it is they signify it is the signs that we think or reason about. ${ }^{18}$ Otherwise, we might ask, what was the point of substituting them in the first place? While Alciphron (like Toland) tells us that a word's failing to signify an idea indicates its meaninglessness, Euphranor's point is that 'empty names' are a common phenomenon in the realm of sign-usage.

So far, Euphranor has shown that words, just like counters, need not always suggest ideas in our minds when we reason and think about them. In instances like these, we 'cash out' the conclusions of our thoughts and reasonings into ideas, just as we cash out poker chips into monetary sums at the end of a game. However, Euphranor also wants to account for those instances in which no 'cashing out' is possible. In these cases, he argues, we should not assume that the terms used are meaningless so long as they serve a purpose..$^{19}$ He explains

there may be another use of words besides that of marking and suggesting distinct ideas, to wit, the influencing our conduct and actions, which may be done either by forming rules for us to act by, or by raising certain passions, dispositions, or emotions in our minds. (AMP 7.5)

Aside from suggesting ideas in the mind, Euphranor observes, words can influence our behaviour either by forming rules or conventions which we act in accordance with, or by giving rise to certain emotions or passions. Euphranor is here employing an observational method in order to discern what makes for useful language. Similarly, in the Introduction to the Principles, Berkeley notes that we can be "affected with the promise of a 'good thing', though we have not an idea of what it is" (PI § 20). Likewise, we can be "threatened with danger sufficient to excite a dread, though we think not of any particular evil likely to befall us". It is clear, Berkeley thinks, in instances like these that words can serve

18 Berkeley also espouses this view in the Principles Introduction where the comparison is between words and algebraic marks. This comparison is also drawn in AMP 7.14

19 See Williford and Jakapi 2009, 104. 
a purpose without suggesting ideas. ${ }^{20}$ We ought not, therefore, conclude that every empty name is meaningless.

Whether or not Euphranor's reply constitutes a rejection of the Lockean theory of meaning in favour of an alternative remains contested. In the literature, there are three discernible interpretations. On interpretation (i) the meaningfulness of words, for Berkeley, is entirely dependent on their ability to induce actions, emotions, or dispositions in the agents who hear and understand them. As Crito puts it later in the dialogue, it is by the "weight" of a word - i.e. its ability to affect us - that we should judge its meaning (AMP 7.10). According to (i), suggesting ideas in the mind is just one of the ways that words can affect us as competent language users - and thus just one of the ways that words can be meaningful. ${ }^{21}$ The Lockean theory, on this reading of Berkeley, fails to provide an exhaustive account of what makes language meaningful and thus ought to be rejected in favour of an account that does; a 'meaning as use' theory.

Both interpretation (ii) and (iii) maintain that Berkeley modified the Lockean theory. Interpretation (ii) entails that Berkeley developed an alternative theory of meaning that is restricted to certain domains of discourse..$^{22}$ Jonathan Bennett, for example, argues that dialogue seven should be seen as a work of "Christian apologetics". On this reading, there are two kinds of discourse; theoretical and non-theoretical (or emotive). The Lockean theory still holds in the case of the former, while Euphranor's 'meaning as use' theory holds in the case of the latter. Interpretation (iii) entails that Berkeley's theory is still 'suggestive' but that the scope of what can be suggested by words is expanded. Proponents of this reading do not accept that Berkeley reduces the meaning of a word to its practical use. Rather, they argue that words like 'Grace' and 'force' are used in the same way as words that stand for relations. Drawing on $\S 89$ of the Principles, they argue that since we have notions (and not ideas) of relations, words like 'Grace' and 'force' must stand for notions. ${ }^{23}$ This is consistent with Euphranor's emphasis on the meaningfulness of words associated with spirits (like 'I' and 'my self') which again stand for notions rather than ideas. (AMP 7.5)

It will become clear that my argument entails Berkeley's anti-abstractionism (developed in the Principles Introduction) and his views about

20 See Belfrage 1986a, 644-645.

21 Proponents of interpretation (i) include Pearce 2017a, 63; Flew 1974; Roberts 2007 (ch.2).

22 Proponents of interpretation (ii) include Bennett 1971, 54; Belfrage 1986; Berman 1994 (ch.6); Ott 2003, 121.

23 Proponents of interpretation (iii) include Williford and Jakapi 2009, 104; Jaffro 2013, 136. 
the dangers of belief in the existence of abstract ideas should lead us to strongly prefer an interpretation in which the Lockean theory is rejected. While I do not intend to take a decisive stance on this issue it follows from my reading that interpretation (i) should be preferred to (ii) or (iii). In the next section, I focus on understanding what Berkeley's treatment of abstract ideas in dialogue seven tells us.

\section{Abstract Ideas in Dialogue Seven}

\subsection{General Words and Abstraction}

Jonathan Bennett claims there is very little connection between Berkeley's account of meaning in dialogue seven of Alciphron and his rejection of abstract ideas. ${ }^{24}$ If Berkeley had intended there to be a connection, he maintains, then it "remains embarrassingly tenuous". Yet, Berkeley's remarks in the Introduction to the Principles quite explicitly indicate that Berkeley saw the two issues as related..$^{25}$ In this section I will argue there is a connection between Berkeley's theory of meaning in language and his rejection of abstract ideas. ${ }^{26}$ I will argue that Berkeley's treatment of abstract ideas in this dialogue reveals that he sees them as an explanatory posit postulated only by those who accept the Lockean theory of meaning. To do so, I will first outline how Berkeley deals with abstract ideas in this dialogue, with a particular emphasis on how his treatment of them changes between the second and third editions of the text.

After Euphranor demonstrates that the 'suggestive' theory of meaning has repercussions that go well beyond just religious discourse, Alciphron finally accepts there may be another use of words "besides that of marking and suggesting distinct ideas" (AMP 7.5). So far, my exposition of Euphranor's view has focused primarily on his observation that religious terminology is used meaningfully despite the failure of words like 'Grace' to suggest ideas. But a great deal of the force of Euphranor's argument also comes from the parity that he demonstrates between religious terms like 'Grace' and more straightforwardly scientific or mathematical terms like 'force' or 'number' (i.e. the kinds of words that free-thinkers would wish to defend as meaningful). Applying the same criteria for meaningfulness to the word 'force' as Alciphron had to 'Grace', Euphranor encourages his opponent to "lay aside the word force and exclude every other thing from your thoughts, and then see

24 Bennett 1971, 45.

25 See Pearce 2017a $(8,13)$.

26 A letter from Berkeley to Samuel Johnson from 24 March 1730 supports my reading. See Hight (ed.) Correspondence 2013 (319). See also Berman 1993 (8). 
what precise idea you have" (AMP 7.9). ${ }^{27}$ Clearly, he argues, the two examples are analogous since, as Alciphron himself puts it, "the same rules of reason and good sense" apply in both the sciences (and mathematics) and religion (AMP 7.3). The meaningfulness of 'Grace' and 'force', Euphranor maintains, stand or fall together.

To anyone familiar with Berkeley's criticisms of Locke in the Introduction to the Principles, and indeed with Locke himself, this exchange and the way in which Alciphron is won over ${ }^{28}$ - might be surprising. For the Lockean recourse in cases like these would be to argue that a general name (like 'force') must signify a general idea. Though he says little about abstract ideas himself, it is perhaps for this reason that Toland who accepts almost verbatim Locke's theory of meaning - focuses solely on the meaninglessness of Christian mysteries. Mysteries, as Toland understands them, are meant to fail to suggest any ideas (CNM 2.2-4). But for Locke (and presumably for Toland) general words, when they are meaningful and not deliberately mysterious, signify general ideas. Locke explains

Words become general, by being made the signs of general ideas; and ideas become general, by separating from them the circumstances of time, and place, and any other idea, that may determine them to this or that particular existence. (EHU 3.3.6)

A word is made general by being assigned to an abstract general idea: an idea which is abstracted from the specific circumstances (time, place, etc.) that would render them particular..$^{29}$ Locke explains this is done out of "reason, and necessity" so that we can communicate ourselves more effectively to one another and for the advancement of knowledge (EHU 3.3.1-7). Why, then, does Alciphron not argue that the word 'force' signifies a general idea? If Alciphron is supposed to be a Lockean about the meanings of words, then his willingness to accept that 'force' does not stand for a precise idea ought to strike us as surprising.

${ }^{27}$ The word 'number' is put under the same scrutiny with the same result (AMP 7.5).

28 This comes with a caveat because towards the end of the dialogue the behaviour of both Alciphron and Lysicles reveals them to be paradigmatic (as Berkeley sees it) free-thinkers: they are not susceptible to reason and are unlikely to be convinced by any amount of compelling argument (AMP 7.23).

29 For more on the mind's ability to render ideas abstract, see EHU 2.11.9. See also Jaffro 2013 (134). 


\subsection{Abstraction in the Second and Third Edition of the Text}

The question of Alciphron's commitment to abstractionism is further complicated by changes that Berkeley made between the second (1732) edition and the third, and final, (1752) edition. ${ }^{30}$ In the third edition of the text, a section is omitted from dialogue seven in which (in the second edition) Alciphron appears to be much more closely aligned with the kind of Lockean views outlined above. ${ }^{31}$ In the second edition, in response to Euphranor's observation that it is possible to comprehend the "force and meaning" of a word even if that word fails to suggest ideas, Alciphron explains that in such cases what you conceive is not a particular but an abstract general idea. He explains:

there is in the human mind, a faculty of contemplating the general nature of a thing, separate from all those particularities which distinguish the individual one from the other...leaving out from [for example] the idea of man, that which is peculiar to the individual, and retaining only that which is common to all men, you form an abstract universal of man or human nature. (AMP $7.5^{*}$ )

This looks very similar to the description of abstraction given by Locke where he explains that

the mind makes the particular ideas, received from particular objects, to become general; which is done by considering them as they are in the mind such appearances, separate from all other existences, and the circumstances of real existence, as time, place, or any other concomitant ideas. (EHU 2.6.9)

Presumably, then, before this section was omitted in the third edition, Berkeley intended to present Alciphron as a straightforward Lockean abstractionist: the kind criticised in the Introduction to the Principles. This means that in the second edition Alciphron is equipped to provide a defence against Euphranor's claim that there is a parity between the cases of 'force' and 'Grace'. Echoing Locke, he explains

30 Any reference with an asterisk is a reference to the 1732 second edition of the text in Jaffro, Brykman, Schwartz (eds) (2010). See the Preface for editorial notes on these different editions. For a history of the publication of Alciphron see Berman $1993(1-2)$.

31 Berman points to some historical explanations of the changes in the third edition. For the most part, I think my reading simply expands on these interpretations. See 1993, 3. 
general names stand, immediately or properly, not for particular but abstract general ideas, which they never fail to excite in the mind, as oft as they are used to any significant purpose. (AMP $\left.7.5^{*}\right)^{32}$

So the first claim is that general names need not be rendered meaningless, even on the 'suggestive theory', so long as they suggest general ideas. The second edition Alciphron then goes on to suggest

as these are not so familiar and obvious to vulgar minds, some men may think they have no idea at all, when they have not a particular idea: but the truth is you had the abstract general idea of man, in the instance assigned, wherein you thought you had none.

Here Alciphron's point is the 'vulgar' can be mistaken in thinking that the words they are using are meaningless. That is, when they fail to appreciate that it is a general idea that a word suggests and not a particular one. This is an unusual point for Alciphron to make and does not appear again in the rest of the dialogue. It does not really appear to help his case - as Euphranor later points out, Alciphron himself had previously insisted that "everyone might easily know for himself whether he has this idea or no" (AMP 7.6*). It is perhaps grounded in a criticism that Berkeley has of Locke's account of abstraction which he puts forward in the Principles Introduction where he picks up on Locke's admission that generating abstract ideas "require[s] some pains and skill" (EHU 4.7.9). Berkeley questions at which stage it is that we learn to do so: it cannot be when we are infants (precisely because of the pains and skill required) and it cannot be when we are adults "for then it seems they are not conscious of any such pains-taking" (PI $\S \S 13-14$ ).

Nonetheless, Alciphron's defence - by means of a more straightforward appeal to Lockean abstract ideas than we see in the third edition is ultimately to no avail, as he is eventually convinced that generality can be accounted for without abstract ideas. Once again, the discussion closely resembles the Principles Introduction, with Euphranor putting forward an account of generality consistent with the one Berkeley develops in the Principles Introduction: ${ }^{33}$

May we not admit general ideas, though we should not admit them to be made by abstraction, or though we should not allow of general abstract ideas? To me it seems, a particular idea may become general by being used to stand for or represent other ideas; and that general knowledge is conversant about signs or general ideas made such by their signification; and which are considered rather in their relative capacity, and as

32 See also AMP $7.7^{*}$.

33 See PI $\S \S 15-16$. 
substituted for others, than in their own nature, or for their own sake. A black line, for instance, and inch long, though in itself particular, may yet become universal, being used as a sign to stand for any line whatsoever. (AMP 7.7*)

Euphranor's claim here is that we can admit of the existence of general ideas without admitting of the existence of abstract general ideas. A particular idea, he argues, can be made to stand for or 'represent' all those to which it bears a "mutual resemblance". In that sense, the idea is 'universal' or 'general', but not in an intrinsic sense. ${ }^{34}$

Prior to the third edition of the text, dialogue seven of Alciphron contains a reiteration of the arguments from the Introduction to the Principles and a Lockean abstractionist who is successfully won over by them. But this exchange is omitted from the final (1752) edition. In the final edition Alciphron is never presented straightforwardly as a Lockean abstractionist and Euphranor is never required to put forward the account of generality that Berkeley develops in PI $\S \S 15-16$. What needs explaining, then, is why Berkeley decided to make this change and what that tells us about his aims in relation to both abstract ideas and language.

\section{Abstract Ideas as Explanatory Posits}

It is clear in the Introduction to the Principles that Berkeley identifies an entailment relation between the Lockean theory of meaning (as I have sketched it) and a commitment to the existence of abstract ideas. ${ }^{35} \mathrm{He}$ explains it is a "received opinion that language has no other end but the communicating our ideas, and that every significant name stands for an idea" (PI § 19). He is clearly pointing to passages in Locke in which an inference is made from the existence of general names to the existence of abstract general ideas. That this is tied to abstractionism is confirmed by the remark that "if there had been no such thing as speech or universal signs, there never had been any thought of abstraction" (PI § 18). This conditional does not explicitly entail that thought of abstraction is dependent on the Lockean theory, but that implication is certainly present (i.e. if the question had never arisen then the Lockean answer would never have been required and, in turn, there would have been no thought of abstraction). ${ }^{36}$

As I have suggested so far, the connection between abstract ideas and the Lockean theory of meaning is less explicit in dialogue seven

34 See PI § 15.

35 See Ott 2003, (118); Jaffro 2013 (135).

36 See Pearce 2017a (17). 
of Alciphron - especially in the third edition where it generally seems to be taken as a given that introspection will reveal the non-existence of abstract ideas. At least, that can be implicitly derived from the various introspective appeals that are made throughout: for example, Alciphron argues that 'laying aside' the word 'Grace' will reveal no ideas (this goes unchallenged by Euphranor) (AMP 7.4). Similarly (in the third edition), it does not take long for Alciphron to accept that there are no ideas pertaining to 'force' or 'number' (AMP 7.5). However, despite the fact that (in the third edition) there is a notable lack of argument either for or against abstract ideas, it is clear that Berkeley is still interested in emphasising the link between the Lockean theory and abstractionism.

I think Crito's role in the dialogue is particularly important for our current purposes. Crito, developing his own argument alongside Euphranor's parity claims, gives an example of how abstract ideas are mere fancies or fictions fabricated by free-thinkers. Like Euphranor, he argues we should begin by observing instances of meaningful discourse and then work out what it is for language to be meaningful. ${ }^{37}$ Such observation, he maintains, will quite clearly reveal the 'suggestive' theory of meaning to be drastically wrong when it comes to religious discourse. Minute philosophers are guilty of not having made the requisite observations and as a result

confound Scholasticism with Christianity, and impute to other men those perplexities, chimeras, and inconsistent ideas, which are often the workmanship of their own brains, and proceed from their own wrong way of thinking. (AMP 7.9)

To assert that ideas ought to be attached to discourse surrounding Christian teaching, Crito argues, is to depart from the reality of Christian faith. Alciphron previously claimed that we ought to look beyond words to the ideas they suggest in order to avoid conflating the 'husk' of a science with the 'thing' itself (AMP 7.2). But Crito's point is that identifying the 'thing' at the centre of Christian religion does not require identifying any ideas. The intention of discourse surrounding Christian doctrines and words like 'Grace' is not, he argues, "to beget nice abstracted ideas of mysteries in the minds of common Christians, this being evidently impossible" (AMP 7.9). Nor, in every day practice, he argues, do Christians see it as any part of their duty to

lay aside the words, shut their eyes, and frame those abstract ideas; any more than men now do of force, time, number, or several other things about which they nevertheless believe, know, argue, and dispute. ${ }^{38}$

37 Earlier in the dialogue, Euphranor encourages us to "make sense of our daily practice" (AMP 7.5).

38 For a similar claim in the Notebooks see NB 552. 
Crito's broader point here is that for a great deal of language to be meaningful, on Alciphron's 'suggestive' theory, there would need to be abstract ideas. This would have to apply to discourse surrounding Christian teaching too. That is, abstract ideas would have to be introduced as an explanatory posit. But, Crito argues, such terms are, and always have been, used meaningfully by ordinary Christians who never even consider the existence of abstract ideas. ${ }^{39}$ So it cannot be the existence of abstract ideas that renders such terms meaningful. Again, this is, at bottom, an empirically-driven claim.

This, I contend, is indicative to Berkeley's own approach to abstract ideas (per se) throughout this dialogue and (insofar as meaning in language is concerned) in the Principles Introduction. As we've seen, Berkeley thinks that were there no general words in language, there would be no belief in the existence of abstract ideas. Moreover, he attributes this to the fact that it is a "received opinion" that meaningful words suggest ideas (PI § 19). Likewise, Crito argues many of the ideas that are supposed to be suggested by general terms are merely the "workmanship of their [that is, free-thinkers'] own brains, and proceed from their own wrong way of thinking" (AMP 7.9, my emphasis). That this goes beyond just religious terms is confirmed by Euprhanor's remark that "when [words] suggest ideas, they are not general abstract ideas" (AMP 7.14). He maintains that this is true of "speech, reason, science, faith, assent in all its different degrees [my emphasis]". As Berkeley sees it, those who accept the Lockean theory of meaning find themselves with a puzzle that needs explaining when it comes to general terms. A puzzle which they explain away by means of the following argument:

(i) All meaningful words suggest ideas.

(ii) General words are meaningful.

(iii) Therefore, general words suggest ideas.

General words do not suggest particular ideas - the word 'human' does not suggest an idea of any particular human - rather they suggest general or abstract ideas. ${ }^{40}$ It is in this sense that abstract ideas, in Berkeley's view, are explanatory posits: they are arrived at by an inference to the best explanation. The problem is that this inference is an illicit one, since there is an alternative way of explaining what makes words meaningful: one that does not require us to (as Pearce puts it) "postulate extremely mysterious entities that are not discoverable in introspection". ${ }^{41}$

How does this approach (reflected in Crito's claims) help us to understand Berkeley's treatment of abstract ideas in dialogue seven?

39 As in PI $\S \S 15-16$, Berkeley's point is that abstraction cannot be a prerequisite for speaking meaningfully. See also MI § 36; Belfrage 1986 (645-646).

40 See EHU 3.3.6.

41 Pearce 2017a, 20. 
It explains the absence of an argument for anti-abstractionism (of the kind developed in the Principles Introduction) and the assumption throughout that introspection will not reveal abstract ideas. Berkeley thinks that abstract ideas are explanatory posits which are introduced once the Lockean theory has been accepted. But in dialogue seven, it is the plausibility of that very theory which is up for debate. As such, it is not necessary to demonstrate that abstract ideas do not exist since, since, Berkeley thinks, once an alternative theory is put in place there is no longer any reason to posit them. There is certainly a sense in which disproving the existence of abstract ideas would show the Lockean theory to be defective, since it would leave proponents searching for the meanings of general terms like 'force' or 'number'. Berkeley does take this kind of approach up until the second edition of the text, but in the third edition omits any such argument. The reason is since abstract ideas are mere explanatory posits, it is sufficient to do away with the problem they are purported to explain - i.e. one thrown up by the Lockean theory of meaning. Providing an argument against abstract ideas, Berkeley finally realises, is unnecessary; like 'raising a dust and then complaining we cannot see' (PI § 3).

Another convincing piece of evidence for this reading is that Berkeley clearly does not see abstract ideas as empirical posits. To anyone familiar with Berkeley's work it should be clear that he does not think the existence of abstract ideas is a hypothesis that is supported by experience. Theory surrounding the existence of abstract ideas, then, is (for Berkeley) divorced from our everyday experience of things. On several occasions Berkeley encourages us to apply our own empirical tests to the doctrine of abstract ideas. Responding to Locke's description of an abstract triangle, for example, he writes:

All I desire is, that the reader would fully and certainly inform himself whether he has such an idea or no. And this, methinks, can be no hard task for any one to perform. What more easy than for any one to look a little into his own thoughts, and there try whether he has, or can attain to have, an idea that shall correspond with the description that is here given of the general idea of a triangle, which is, neither oblique, nor rectangle, equilateral, equicrural, nor scalenon, but all and none of these at once? (PI § 13)

The emphasis here is placed on the ease with which any of us can identify what our ideas are like. Berkeley clearly saw this empirical evidence as justification for rejecting abstract ideas. Berkeley explicitly maintains that no one, if they really examine the empirical evidence on offer to them, will conclude that their ideas are abstract. There must, therefore, be some other reason why the doctrine of abstraction is so widespread. That reason, Berkeley thinks, is that abstract ideas serve to 
explain how general terms find meaning in the widely accepted Lockean theory.

\section{Conclusion}

In this paper I have argued (contra Bennett) that Berkeley does see a relation between abstractionism, a commitment to the existence of abstract ideas, and the Lockean theory of meaning in language, in which for a word to be meaningful it must stand for an idea. However, I have demonstrated that Berkeley does not see anti-abstractionism, his rejection of the existence of abstract ideas, as a premise in his argument against this theory of meaning. Rather, Berkeley sees this theory as giving rise to the widespread acceptance of abstractionism. It is for this reason, I have argued, that ultimately (in the final edition of the text) Alciphron is not presented as an abstractionist. As Berkeley sees it, abstractionism only arises once the Lockean theory is accepted. But the aim of dialogue seven is to show that this theory ought not to be accepted; based on the empirical observation that language is meaningful even when words fail to stand for ideas. In the Introduction to the Principles Berkeley aims to demonstrate the absurdity of abstractionism, while on several occasions suggesting that it follows from a "received opinion" concerning meaning in language (PI § 19). In dialogue seven of Alciphron, Berkeley goes back and shows the absurdity of this 'received opinion'. This, in turn, supports his arguments in the Principles Introduction. ${ }^{42}$

This reading explains why Berkeley, in the final edition of the text, never explicitly tackles the doctrine of abstraction, but instead focuses on undermining the reasons why the Lockean theory of meaning is accepted. It also makes sense of Berkeley's claim that the Principles Introduction concerns "the nature and abuse of language" - an otherwise confusing claim (PI § 6). So far as Berkeley's own, positive theory of meaning in language goes, my reading favours what I previously called interpretation (i). On this interpretation, Berkeley completely rejects the Lockean theory in favour of a 'meaning as use' account. Finally, this reading can be seen to give rise to an interesting (albeit, at this point, speculative) historiographical insight. Thomas Reid famously saw Berkeley as furthering the 'Way of Ideas' to it's inevitable, sceptical conclusion. But my emphasis on the observational method by which Berkeley undermines the plausibility of the existence of abstract ideas places him alongside the likes of Reid who identified empirical reasons for rejecting (what he called) 'ideism'. Of course, Berkeley's point is restricted to abstract ideas

42 For Berkeley's early views on language, see Belfrage 1986a, 1986b; Pearce 2017a (ch.2). 
alone, but nonetheless this reading makes him look more Reidian than Reid ever seemed willing to acknowledge. ${ }^{43}$

\section{Bibliography}

\section{Primary Sources:}

$\mathrm{CNM}=$ John Toland Christianity Not Mysterious Philip McGuiness, Alan Harrison, Richard Kearney (eds.) The Lilliput Press: Dublin 1997 (1696).

DHP = George Berkeley. Three Dialogues Between Hylas and Philonous. In Clarke 2008 (1713), 151-242.

EHU $=$ John Locke An Essay Concerning Human Understanding 1975 (1690)

Edited by Peter H. Nidditch (Oxford: Oxford University Press).

MI = George Berkeley George Berkeley's Manuscript Introduction: An Editio Diplomatica. Edited by Bertil Belfrage. Oxford: Doxa, 1987.

NB = George Berkeley Philosophical Commentaries George Hasson Thomas (ed.). The Philosophy of George Berkeley, Ohio: Garland 1989.

PHK $=$ George Berkeley. A Treatise Concerning the Principles of Human Knowledge. In Clarke 2008 (1710), 67-149.

$\mathrm{PI}=$ Introduction to PHK.

AMP = George Berkeley. Alciphron, or the Minute Philosopher [third edition]. In Clarke 2008 (1752), 269-313.

AMP $^{*}=$ George Berkeley. Alciphron, or The Minute Philosopher [second edition]. In Jaffro, Brykman, and Scwartz 2010, 17-274.

\section{Secondary Sources:}

Margaret Atherton 'Berkeley's Anti-Abstractionism' Essays on the Philosophy of George Berkeley Ernest Sosa (ed.) D. Reidel Publishing Company: Holland (1986), 45-60.

Bertil Belfrage 'Berkeley's Theory of Emotive Meaning' History of European Ideas 7:6 (1986a), 643-649.

Bertil Belfrage 'Development of Berkeley's Early Theory of Meaning' Revue Philosophique de la France et de l'Étranger 176: 3 (1986b), 319-330.

Jonathan Bennett Locke, Berkeley, Hume: Central Themes Clarendon Press: Oxford (1971).

David Berman Berkeley: Idealism and the Man Clarendon Press: Oxford (1994). David Berman (ed.) Alciphron, or the Minute Philosopher: In Focus Routledge: London and New York (1993).

43 Thanks to Manuel Fasko and Kenneth Pearce for constructive comments on drafts of this paper, and to participants at the International Berkeley Society conference in Torun in October 2017. 
Martha Brandt Bolton 'Berkeley and Mental Representation: Why Not a Lockean Theory of Ideas?' New Interpretations of Berkeley's Thought Stephen H. Daniel (ed.) (2008), 77-106.

Desmond Clarke (ed.) Berkeley: Philosophical Writings Cambridge University Press: Cambridge (2008).

Anthony Flew 'Was Berkeley a Precursor to Wittgenstein?' in Hume and the Enlightenment: Essays Presented to Ernest Campbell Mossner W. B. Todd (ed.) Edinburgh University Press (1974).

Marc A. Hight (ed.) The Correspondence of George Berkeley Cambridge University Press: Cambridge (2013).

Laurent Jaffro, Genevieve Brykman, and Claire Schwartz (eds.) Alciphron: English Text and Essays in Interpretation Hildesheim: Georg Olm Verlag (2010).

Laurent Jaffro 'Language and Thought' in The Oxford Handbook of British Philosophy in the Eighteeneth Century Oxford University Press: Oxford (2013), 128-148.

Walter Ott Locke's Philosophy of Language Cambridge University Press: Cambridge (2003).

Kenneth L. Pearce Language and the Structure of Berkeley's World Oxford University Press: Oxford (2017a).

Kenneth L. Pearce 'Berkeley's Philosophy of Language' in The Bloomsbury Companion to Berkeley Bloomsbury: London and New York (2017b), 458-483.

Samuel Rickless 'The Relation Between Anti-Abstractionism and Idealism in Berkeley's Metaphysics' British Journal for the History of Philosophy 2014, 723-740.

John Russell Roberts A Metaphysics for the Mob: The Philosophy of George Berkeley Oxford University Press: Oxford (2007).

Kenneth Williford and Roomet Jakapi 'Berkeley's Theory of Meaning in Alciphron VII' British Journal for the History of Philosophy 17:1, (2009), 99-118.

\section{Summary}

The argument against the existence of abstract ideas in the Introduction to the Principles is one of Berkeley's most famous arguments. His view that all our ideas are particular and that the Lockean process of abstraction is impossible pervades his philosophy well beyond the Introduction and even the Principles itself. The role Berkeley's anti-abstractionism plays in his wider philosophy has been discussed by several commentators in relation to his arguments for immaterialism. However, a great deal less has been said about its role in Berkeley's philosophy of language. Dialogue VII of Alciphron is Berkeley's most extended discussion of language and where he develops his alternative to the Lockean theory of meaning. In this paper, by focusing on this dialogue, I examine the crucial connection that Berkeley identifies between how we use language and the supposed 
existence of abstract ideas. I argue that, as it turns out, we should not see Berkeley's anti-abstractionism as playing a role in his argument against Lockean semantics of language. Instead, Berkeley's view is that by providing an alternative to Locke's theory he removes the need for abstract ideas as explanatory posits. Only once the Lockean theory is accepted, Berkeley thinks, are abstract ideas posited. I argue this reading of the relationship between language and abstract ideas explains why, between early editions of Alciphron and the final edition, Berkeley alters the position of the dialogue's antagonist, Alciphron, from someone who straightforwardly adopts Lockean abstractionism to someone who does not.

Keywords: Berkeley, language, ideas, abstraction, meaning, Locke

\section{Streszczenie}

\section{Berkeley na temat stosunku pomiędzy ideami abstrakcyjnymi a językiem w siódmym dialogu Alkifrona}

Jednym z najsłynniejszych argumentów przedstawionych przez Berkeleya jest jego argumentacja przeciwko istnieniu idei abstrakcyjnych zawarta we Wstepie do Traktatu o zasadach poznania ludzkiego. Pogląd głoszący, że wszystkie nasze idee są konkretne i że nie jest możliwy Locke'owski proces abstrakcji, przewija się przez całą jego filozofię, wykraczając nie tylko poza Wstęp, ale i treść Traktatu. Wielu komentatorów omawiało rolę Berkeleyowskiego antyabstrakcjonizmu w jego filozofii, szczególnie w odniesieniu do głoszonej przezeń tezy immaterialistycznej, dużo mniej uwagi poświęcono jednak roli owej argumentacji w Berkeleyowskiej filozofii języka. Najbardziej rozwinięte omówienie kwestii języka zawarte jest w siódmym dialogu Alkifrona, w którym Berkeley przedstawia alternatywną wobec Locke'owskiej koncepcję znaczenia. W niniejszym artykule koncentruję się na tym dialogu i poddaję badaniu zasadniczy związek, jaki zdaniem Berkeleya występuje pomiędzy sposobem, w jaki posługujemy się językiem, a domniemanym istnieniem idei abstrakcyjnych. Okazuje się, że nie powinniśmy uważać, iż Berkeleyowski antyabstrakcjonizm odgrywa jakąś rolę przeciwko Locke'owskiej semantyce języka. Stanowisko Berkeleya wydaje się inne: przedstawiając teorię alternatywna, usuwa on potrzebę odwoływania się do idei abstrakcyjnych jako koniecznego założenia w procesie wyjaśniania. Berkeley uważa, że istnienie idei abstrakcyjnych zakładamy tylko wtedy, gdy przyjmujemy teorię Locke'a. Jak sądzę, taka interpretacja relacji pomiędzy językiem a ideami abstrakcyjnymi wyjaśnia, dlaczego w czasie pomiędzy wcześniejszymi wydaniami Alkifrona i jego edycją ostateczną Berkeley zmienia stanowiska będącego jego antagonistą Alkifrona, który w późniejszych wydaniach dzieła porzuca Locke'owski abstrakcjonizm.

Słowa kluczowe: Berkeley, język, idee, abstrakcja, znaczenie, Locke 